Article

\title{
Could Mapping Initiatives Catalyze the Interpretation of Customary Land Rights in Ways that Secure Women's Land Rights?
}

\author{
Gaynor Paradza ${ }^{1, *(\mathbb{D})}$, Lebogang Mokwena ${ }^{2}$ and Walter Musakwa ${ }^{3}$ \\ 1 Public Affairs Research Institute, Forest Town, Johannesburg 2193, South Africa \\ 2 New School for Social Research, Department of Sociology, New York, NY 10011, USA; \\ mokwg590@newschool.edu \\ 3 Future Earth and Ecosystems Research Group, Department of Urban and Regional Planning, \\ University of Johannesburg, Johannesburg 2028, South Africa; wmusakwa@uj.ac.za \\ * Correspondence: gaynorp@pari.org.za or ggparadza@gmail.com; Tel.: +27-748-220-487
}

Received: 31 July 2020; Accepted: 17 September 2020; Published: 23 September 2020

\begin{abstract}
Although land forms the basis for marginal livelihoods in Sub-Saharan Africa, the asset is more strategic for women as they usually hold derived and dependent rights to land in customary tenure areas. Initiatives to secure women's land tenure in customary areas are undermined by the social embeddedness of the rights, patriarchy, lack of awareness by the communities, legal pluralism, and challenges of recording the rights. As pressure on customary land tenure increases due to foreign and local land-based investment interests, land titling initiatives, tourism, and mineral resources exploration, communities and women within them are at real risk of losing their land, the basis of their livelihoods. Women stand to lose more as they hold tenuous land rights in customary land tenure areas. Accordingly, this study analyzes case studies of selected mapping initiatives in Sub-Saharan Africa to interrogate the extent to which mapping both as a cadastral exercise and emerging practice in the initiation of participatory land governance initiatives, catalyze the transmission of customary land rights in ways that have a positive impact on women's access to land in customary land tenure areas. The results indicate that mapping initiatives generate opportunities, innovations, and novel spaces for securing women's access to land in customary tenure areas which include catalyzing legislative changes and facilitating technology transfer, increasing awareness of women's interests, providing opportunities for women to participate in decision-making forums, providing a basis for securing statutory recognition for their land rights, and improving natural resource stewardship. The potential challenges include the community's capacity to sustain the initiatives, the expense of the technology and software, widespread illiteracy of women, power asymmetries and bias of the mapping experts, increased vulnerability of mapped land to exploitation, the legal status of the maps in the host community and /or country, compatibility with existing land recording systems, statutory bias in recording land rights and the potential of mapping initiatives to unearth existing land boundary conflicts. These challenges can be mediated by sensitive planning and management to ensure real and sustainable land tenure security for women. The paper contributes to debates around customary land tenure dynamics, specifically the issues pertaining to registration of primary and derived customary rights to land. These includes policy debates and choices to be made about how best to secure tenuous customary land rights of women and other vulnerable people. The paper also contributes to our understanding of what instruments in land registration toolkits might strengthen women's land rights and the conditions under which this could be done.
\end{abstract}

Keywords: customary; land; tenure; women; mapping; Sub-Saharan Africa 


\section{Introduction}

Land in Sub-Saharan Africa is held under various tenure systems which include freehold, leasehold, and customary. Customary land tenure is the majority of land holding in Africa, accounting for $78 \%$ of the land holding [1]. The relative abundance of land held under customary tenure means that it is a critical asset for the poor who rely on subsistence for their survival [2]. The abundance of land under customary tenure coupled with the fact that it is allocated in some circumstances for free as birthright or upon marriage marital render it one of the most accessible land for women who are overrepresented among the poor. However, these land rights are increasingly vulnerable to conflict, increasing land demand fuelled by rapidly changing land markets, urbanization, and large scale land-based investments [3,4]. This leaves women vulnerable to lose the land at a time when land rights are increasingly contested. The insecurity occasioned by the instability of marriage- (which has far-reaching implications at both the household and at the community levels)-has introduced new stresses to women's sustained land access as these key institutions through which women negotiate access to customary land are increasingly in a state of flux $[5,6]$. The impact on women's land rights under customary tenure land is that they find themselves dependent on ever shrinking, less fertile, and increasingly expensive pieces of land. Among the factors that account for the vulnerability of women's land rights in customary tenure areas, has been women's invisibility or secondary tenure status [5]. This secondary tenure status arises out of their securing land on the back of primary land rights, which, in patriarchal customary institutions, are held by men. A review of land mapping initiatives in patrilineal systems illustrates that these could potentially provide some relief and generate opportunities for women to secure their customary land rights by increasing the visibility of derived land rights, generating opportunities for women to participate in land decision-making fora, and generate opportunities for women to articulate their land needs in land governance institutions.

Mapping of land using geospatial information technologies such as global positioning systems (GPS) are some of the increasingly popular innovations that are used by diverse constituencies working to record and secure customary land tenure rights. Mapping can also be in the form of mental mapping, ground mapping, participatory sketch mapping, transact mapping, and participatory 3-dimensional modeling [7-11]. Combining geospatial information technology and social science mapping often yield holistic mapping results $[4,7,8]$. These methods have been used by international and multilateral donor community, philanthropic organizations, local and transnational non-governmental organizations (NGOs) and communities, customary authorities, the national government and local government $[4,7,8]$. Participatory land and natural resources mapping initiatives have emerged for a variety of reasons. These include recording land rights, capturing land use and land cover, boundary mapping, and indigenous knowledge, biodiversity mapping and conflict resolution $[9,11]$. As a people-centered approach to improving (and making more transparent) overall land governance, participatory mapping initiatives have indeed emerged as one of the key ways to amplify the voices of usually rural communities and those who are most vulnerable within them vis-à-vis land tenure and general natural resource access and use. Participatory mapping consists of facilitating a community-wide discussion about and agreement on the boundaries of the land and natural resources that are communally owned or used. It is also about the various uses of the land and natural resources that are available within the communal area whose boundaries are being mapped [8,9]. Participatory mapping initiatives have become one of the experimental ways through which alternative processes for enhancing inclusive, gender-sensitive, sustainable, and informed land governance in Sub-Saharan Africa has been pursued. Participatory mapping improves access to spatial information [8]. Mapping exercises have entailed or have at least aimed to inform the conversion of the community participatory maps into formal, location-based, geographic maps for incorporation into or for the revision of existing cadastral databases. In customary land tenure areas, these initiatives have also been deployed to facilitate land claims and land stock taking [10]. 


\section{Women and Land Tenure Vulnerability in Customary Tenure Areas}

Women need secure access to land because they are highly dependent on the resource for their welfare, productivity, and empowerment $[5,12,13]$. Women need land to fulfill their productive and reproductive responsibilities. When women control land, they have increased bargaining power in their communities and households [12,13]. Increased women's access to land has a positive impact on children's welfare and education in Sub-Saharan Africa [2,14,15]. Securing access to land in a customary land tenure area provides a platform through which women can negotiate access to community membership, employment opportunities, assistance with childcare. Women also use customary land as a fallback insurance if they lose their residence on the dissolution of marriage [5]. The terms on which customary land rights are secured render this the most accessible land tenure to women in Sub-Saharan Africa [16].

Customary tenure is a term to describes the complex, dynamic, and evolving multi-faceted and transformational ideas and practices around land tenure [17,18]. The nature of customary land rights is that they are not registered [16]. Under customary tenure, land is held under overlapping tenures of individual household and common property $[5,16]$. The rights are guaranteed by diverse regulatory regimes $[19,20]$. Customary lands are held under customary laws which is one of a host of other laws and regulations that include statutory and non-statutory regimes. As a result of the existence of diverse laws and regulations, there is ambiguity, contradiction and loopholes in the application and interpretation of laws in the governance of customary lands [5,21]. Although customary laws and rules are not consistent across diverse groups, they are generally controlled by male biased traditional leaders who control the land on behalf of the communities [5,22,23]. Although the term is contested, [21] identified various common features of customary land tenure. These include overlapping rights, shared and inclusive rights, social and politically stable resource boundaries and controlled through guaranteeing of rights, enforcing of rights, and dispute resolution [4,18,24]. Although internal mechanisms for allocating land are diverse, people gain access to land by membership of a community through birth, marriage, or bush clearing [10]. Land beneficiaries have conditions attached which differ between men and women.

Women's land access under customary tenure varies from place to place with substantial differences between patrilineal and matrilineal societies although male kin control land allocation in both systems $[2,16,25]$. Although the processes are not homogenous, in Zambia, for example, in matrilineal societies, descent and inheritance follows the mother's line, while in patrilineal systems, descent follows the father's line [16,25]. Land allocation is made to male members by lineage in patrilineal societies [16]. This publication focuses on patrilineal systems, where women's access to land is informed by their relationship between men and women as spouses, siblings, fathers, daughters, sons, and brothers [26]. Women hold secondary and derived land rights. This secondary tenure status arises out of their securing land on the back of primary land rights, which, in patriarchal customary institutions, are held by men [6]. Although traditional leaders may allocate individual land rights to single women - they rarely allocate land to married women in their own right $[5,16]$. Customary law seems to have few provisions for divorced women and even fewer for single women [5,27]. Divorced women are vulnerable to lose their marital customary land rights upon the dissolution of the marriage $[5,16,27]$. Inheritance is also gender related with women's rights to inherit land disproportionately limited [5,27]. The ambiguity in the interpretation of laws and statutes is viewed as consistently discriminating against women in the arena of customary land claims by allowing those with power to oppress the powerless. Examples include the vulnerability of widows to land dispossession through unequal and inconsistent application of the law $[16,25,28,29]$ and use of the law to discredit women involved in disputes over customary land. Another characteristic of customary land tenure is that community members often rely upon common resources such as forests, grazing lands, and water sources for their livelihoods and daily needs. Women also rely on these common resources for firewood and medicinal plants. Community members are generally considered the "co-owners" or rightful users of such land [4]. The situation has been changing as labor and monetary 
markets also mediate women's access to land in customary land tenure areas $[5,16]$. The stock of land held under customary tenure has been declining. This is because of conversion to leasehold and freehold, climate change losses, increasing land demand fuelled by rapidly changing land markets, urbanization, and large-scale land investments, globalization, structural adjustment, and perceptions that other tenure forms are more secure [3,5,18,30-32]. The pressures to formalize or register customary land tenure is driven by those who believe that this would modernize the tenure and attract investment, make it easier to record the land rights, incentivize users to take better care of resources and use the land as collateral $[4,33,34]$. The pressures on customary land tenure are inducing shifts in women's land rights and undermining their fragile tenure [6]. Market pressures undermine women's customary land rights as women generally lack resources to secure land on the market. The market pressures also affect common lands that women rely on for firewood as these are vulnerable to disposal on the land markets. The market pressures also result in individualization and registration of land. Women's tenure is compromised as family land is usually registered in the name of a single individual in the household who is usually male. The pressures on customary land arising from land scarcity, rapid population growth, and increasing land individualization erode the customary safeguards in place to secure women's land tenure security [35-38]. Women's customary tenure is compromised when disputes arise in land negotiations because they have limited access to decision-making forums and institutions of justice. $[6,27,39]$. The invisibility, secondary tenure status, marginalization of women from customary land governance forums and challenges of representing customary land rights effectively at law increase the vulnerability of women's customary tenure land rights [40-42]. As a result, when land is transferred to large scale investors, the attendant decision-making, apportionment of costs and benefits marginalizes women $[30,43]$. This is because women are excluded from decision-making and their invisible land claims are not acknowledged in the calculation of losses for compensation purposes. In addition, marriage, one of the institutions through which women gain and maintain access to customary land, has been undermined by divorce, increased mobility, death, and economic independence of women. The insecurity occasioned by the instability of marriage introduces new stresses to women's sustained land access as these key institutions through which women negotiate access to customary land are increasingly in a state of flux [5].

The transformation and sometimes privatization of common land (like forests, grazing areas) arrangements undermine women's land claims in customary tenure areas by undermining existing structures and arrangements for managing the vulnerability of people and women who depend on these. This is through, for example, opening up land for speculation by outsiders and increasing inequality among the different groups [31,44].

The impact on women who depend on customary tenure land is that they find themselves dependent on ever shrinking, less fertile, and increasingly expensive pieces of land. Mapping is an increasingly popular mechanism for demarcating land for purposes of transfer, valuation, and registration. This review of land mapping initiatives illustrates that these could provide some relief and generate opportunities for women to secure their customary land rights by increasing the visibility of derived land rights, generating opportunities for women to participate in land decision-making fora, and generate opportunities for women to articulate their land needs in land governance institutions.

\section{Materials and Methods}

The paper draws on secondary data. This consists of secondary analysis of published case studies of work that was carried out in Benin, Liberia, Lesotho, Democratic Republic of Congo, South Africa, Rwanda, Madagascar, Uganda, and Mozambique. Table 1 summarizes the cases, the nature of intervention, and sources available on the intervention. The cases were purposively selected to reflect common themes of mapping on land under customary tenure, diversity across the Sub-Saharan Africa, and cases that provided a reflection and/or impact on women's land rights. Table 1 shows that mapping interventions were undertaken as a major or minor part of other interventions to record and delineate customary land tenure. This was in Mozambique, Uganda, Madagascar, Democratic Republic of Congo, 
Benin, and Lesotho. In all the cases, mapping was used to contribute to clarify land rights of land under customary tenure. The sources include inception reports, self-authored reports by implementing institutions, technical reports, and peer reviewed publications.

Table 1. Case study summaries.

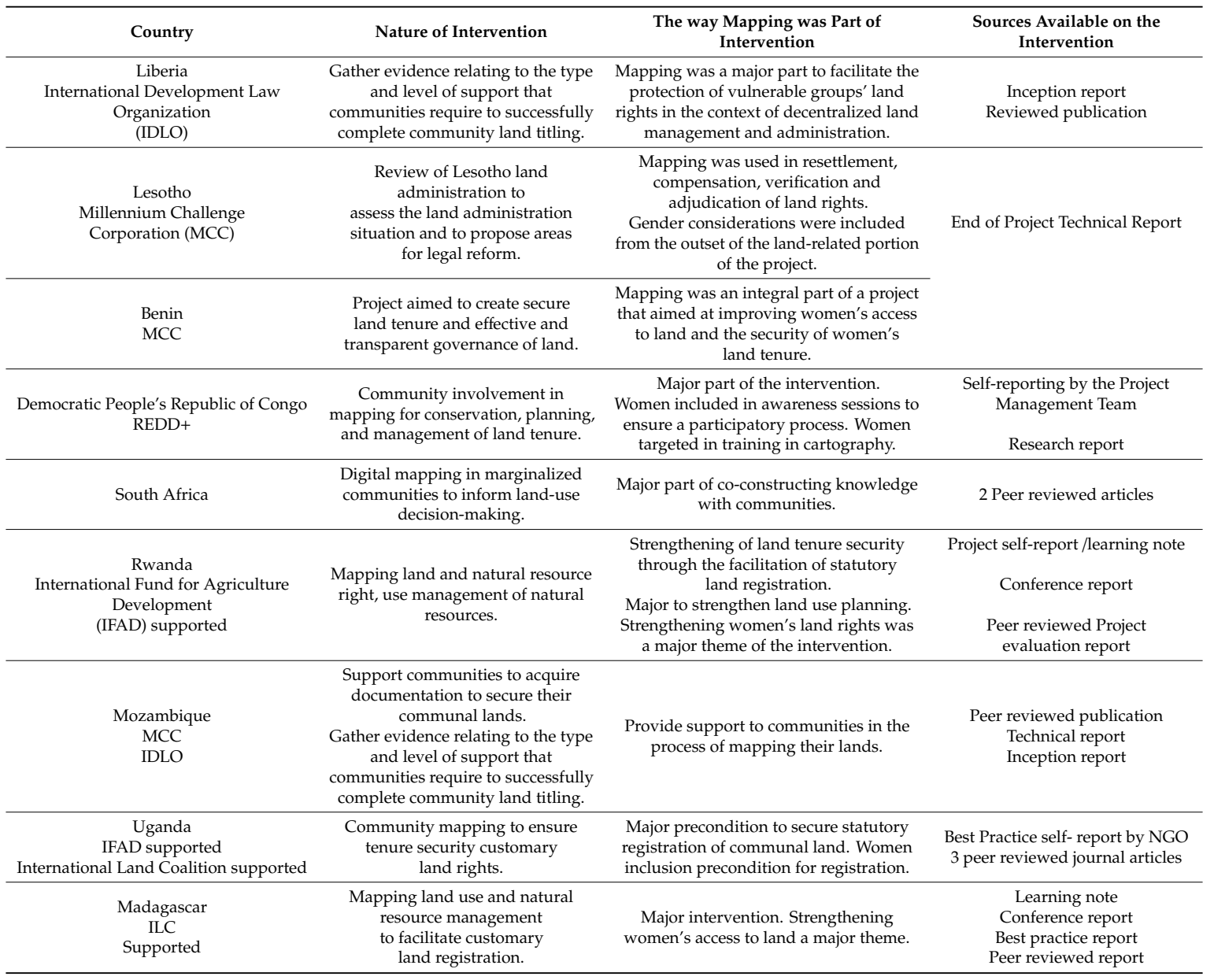

The cases were analyzed using thematic analysis. The review of the selected case studies followed a two-step thematic analysis. The first step analysis focused generally on mapping in customary area lands. The purpose was to capture the context, reasons, and institutional arrangements for mapping customary tenure land. The findings of this analysis are described in Sections 3.1 and 3.2 of the paper. The secondary analysis focused on data in the selected cases related to consideration of women's land rights in the mapping initiatives. These findings are the focus of Section 3.4. The primary focus of this study was to interrogate the potential of customary land mapping initiatives to strengthen women's land tenure in Sub-Saharan Africa. The point being to explore the potential of the intervention so that the findings of the exploratory work can used to inform policy making around strengthening women's land rights in customary land tenure areas. The limitations of the methodology include the inconsistency of sources that authors relied on which range from self-reported to peer reviewed publications. This inconsistency posed challenges in the consistency and depth of information available. The use of existing data to fit new research questions focusing on (a) the impact of mapping on customary land and (b) the potential of the intervention to increase tenure security for women's land rights was limited by the fact that the authors had no other knowledge of these cases outside the written information. For example, none of the cases had information on the gender disaggregated indicators, long term impact of the initiative on women's land tenure rights in customary tenure areas, or the strategies for securing women's land tenure status outside the locality. The authors 
drew on their own experiences in mapping and land tenure security to strengthen their insight and analysis. Although the article would have benefitted from more information on the process, strengths, and challenges of the primary research, the authors believe that the diversity of cases analyzed generate rich data, diverse contexts, and local experiences of customary land mapping in Sub-Saharan Africa. The authors believe that the selection of cases and the data can be reliably used as a basis for critically analyzing the potential of mapping as a tool for increasing customary land tenure security for women in Sub-Saharan Africa.

\section{Results and Discussion}

\subsection{Overall Justification for Mapping Initiatives in Customary Land Areas}

Mapping initiatives are closely tied to a broader process of land regularization or documentation. Maps are an effective medium for a large variety of development projects. Maps enhance stakeholders' ability to visualize space, how it is used, land use and land cover changes, and how the demarcated space relates to adjacent parcels of land and resources. Maps provide a platform for stakeholders to gain an appreciation through a visual-even if rudimentary-instrument, the nature of the resourceand land-related problems that the community may be facing. The International Development Law Organization (IDLO) implemented the Community Land Titling Initiative in Liberia, Uganda, and Mozambique to experiment with different models through which to support communities in the acquisition of knowledge regarding the legislative requirements and process for securing government documentation or titles for their communal lands [4,9].

Mapping can enable stakeholders to visualize the spatial distribution of complex problems $[8,10]$. For example, Mozambique's land delineation process enabled communities to define their land claims in customary land [8]. Mapping can help stakeholders to understand the relations over land and natural resources and illustrate important social, traditional, and historical as well as indigenous knowledge [10,45]. Mapping is also used to carve out the socio-political environment, especially institutional structures that govern land [46], while also creating the possibility for good land governance by enhancing transparency. Mapping empowers communities by providing them with opportunities to convert tacit indigenous knowledge embedded in people's memories-especially those of elders'into external usable knowledge [10]. Mapping is also used to highlight environmental vulnerability by marking coastal erosion and riverine flood lines. In Kenya, GIS and remote sensing techniques where used for natural resource management and for project monitoring [44]. Mapping increases stakeholders' awareness of, for example, land use, land demand, and or population density. In the Democratic Republic of Congo, mapping was used to devolve central control over resources as mapping of customary land boundaries by local authorities and traditional leaders and chiefs enabled these lower levels of governance to claim autonomy in decision-making over land from the central government. The initiative also enabled communities to gain knowledge of the contractual issues that could affect their land rights and capacity to participate in decision-making processes. The intervention also facilitated the management and use of village land and natural resources, monitoring of loss of forest cover, and helped communities identify land rights and confirm land limits [7]. The recording of land claims on a map increases the visibility of the claims and improves communities and women's chances of securing their tenure as these maps become the documentary evidence of communities' claim to the land. Within communities, participatory mapping can generate discussions and lead to the resolution of inter- and intra-community disputes over natural resources $[9,10]$. In terms of land use, structured participatory mapping processes can provide communities with an opportunity to develop land use plans to inform primary and secondary land rights. This will enable them to monitor changes in the environment and resource distribution [7]. In uSuthu, Swaziland, the International Land Coalition supported-IFAD mapping intervention enabled communities to plot water sources and soil types. Through this mapping exercise, extension staff could advise traditional leaders on land designation as well as generate guidelines for future land and resource allocation. Mapping is 
commonly used to generate local land occupation plans, support the adjudication of land claims and the issuance of legal certificates of occupation by people with unrecorded customary land rights [44]. Mapping was used in Mozambique to enable communities to claim and register interest in land, establish the spatial extent of the Direito de Uso e Aproveitamento dos Terras (DUAT) or interest in the land or 'the right of use and benefit of customary land' $[8,39,46]$, and mitigate the risk of boundary contestation with neighboring communities.

In Mozambique, the Millennium Challenge Corporation (MCC) funded mapping enabled communities to realize the extent of their land, thereby making it possible for them to make informed decisions about land use and enhance their capacity for informed, evidence-based engagements, and negotiation with potential investors [46]. Mapping can support the recording and intergenerational transfer of knowledge which sustains traditional indigenous knowledge and promotes ecosystem resilience [10]. Mapping can facilitate negotiation among community members regarding resource priorities. Mapping can be used to inform advocacy and enhance community cohesion in the face of land-related challenges. In South Africa, where spatial injustice is represented by skewed distribution of land, mapping became a political exercise to represent diverse narratives of land history. These narratives are used to support restitution land claims by communities [47].

In Madagascar, IFAD worked with rural communities who were previously barred from owning land. In 2005, the government introduced a land policy to improve land tenure for these groupings, thereby enabling rural communities to formalize their land rights and garner tenure security. As a result of the government's new land policy, communities were issued with certificates and existing titled ownership, parks, and reserves were mapped using existing records that were in turn validated by the communities. Customary rights were also identified and mapped using satellite images of the communes. This was complimented with multi stakeholder land tenure diagnosis, planning, and participatory community land use maps [10]. Maps can be used to represent a first attempt at a geographical representation of natural resources and therefore, a document that can be used to negotiate rights to land and natural resources. In Uganda, pressure over land and natural resources exposed customary land users to violation of their land rights [47-49]. The situation is especially bad in Karamoja, an area richly endowed with mineral resources where investors are rushing to claims concessions. Customary land rights held by pastoralists remained vulnerable because the communities lacked resources and mechanisms to demarcate their land. The communities' lack of awareness of their rights, coupled with the government's delays to implement legal provisions aimed at increasing the community's control over customary tenure land [49], compounded the situation. In order to obtain a certificate of community ownership or a freehold title over communal land in Uganda, a community has to establish a Community Land Association (CLA), the first step of which requires mapping and boundary harmonization $[47,48]$. The community map is a precondition for the registration of the Communal Land Association. The Uganda Land Alliance, with support from Dan Church Aid and the Ford Foundation, carried out community mapping of communal land resources to support the registration of the Communal Land Associations. The mapping resulted in the identification of customary lands in the area, boundaries, grazing lands, watering points, areas for gathering firewood, and shrines. The mapping showed that customary land was vulnerable to land grabbing [48]. Finally, on the back of the recognition of immense agricultural land tenure pressures in Rwanda and their negative impact on food security, the International Fund for Agricultural Development (IFAD) provided support for the Kirehe Community-Based Watershed Management Project (KWAMP). While the objective of KWAMP was not directly about enhancing participatory land governance through community land and resource mapping, a key component of the project necessitated this approach. In particular, under the Water and land use management component of the project, the intention was addressing challenges and weaknesses in the existing regulatory framework while also granting enhanced tenure security for farmers by registering their land rights. The government developed simple methods by which people could map their own boundaries using satellite images and aerial 
photography [44]. These images were then used to inform the parceling out and titling of land to those farmers receiving poverty reduction interventions.

\subsection{Institutional Arrangements for Mapping Initiatives}

Mapping initiatives that have been undertaken in Liberia, Mozambique, Benin, Lesotho, and Uganda are multi-stakeholder in their design. Diverse actors who range from community-based organizations to development partners initiate the process. These stakeholders play differing roles each of which contributes to increased land tenure security of women in customary lands. Development partners integrate gender into their strategies, governance, metrics, organizational structure, and budgets [46]. In the case of Liberia, Mozambique, and Uganda, the International Development Law Organization (IDLO) was the central initiating actor with funding from the United Kingdom Department of International Aid (UKAid), Australian Aid (AUSAid), as well as from the Bill and Melinda Gates Foundation and the Open Society Foundation $[4,8]$. In the case of Benin and Lesotho, the Millennium Challenge Corporation (MCC) has played the leading role [46]. The World Wide Fund for Nature (WWF) has similarly played a strategic role in the Democratic Republic of Congo [7] while IFAD provided land officers to support the districts in Rwanda and also engaged in community sensitization as part of broader land demarcation pilots in Rwanda. In Madagascar, IFAD supported and funded the project to support development in the Menabe and Melkay regions [10]. In Benin, local governments play an important role in registration and are responsible for issuing certificates and upholding land information [44]. The WWF in the DRC worked systematically to include customary land authorities in the mapping exercises. This was through their inclusion at inception and validation activities. The WWF provided computers and training for young men and women on using the mapping technology [7]. The MCC facilitated women's land tenure security by insisting on the revision of gender blind and discriminatory legislation as a pre-condition of their involvement. This precipitated the revision of discriminatory statutory laws that undermined women's land tenure status in Lesotho [46]. In Liberia, Mozambique, and Uganda, the traditional leaders were responsible for identifying sites that are of cultural significance. They also assisted the technicians to identify and verify all community boundaries [8]. Traditional leaders also supported the mapping by participating in the discussions and facilitating the participation of their communities.

The government of Rwanda initiated the 2008 National Land Centre that was responsible for overall land management and mapping [10]. The central government and its agencies were also responsible for implementing the Land law and formulating Land Policies that framed the mapping initiatives. The gender sensitive Land Policy and the Organic Land Law No. 08/200515, which is the basis of a legal framework for land management and administration in the country, prohibits any discrimination based on sex in matters relating to ownership or possession of rights over the land, as the wife and the husband have equal rights over the land [50]. This legislation provided a gender sensitive policy and legislative environment for grounding the customary land tenure mapping initiatives. The Ministry of Lands, Environment, Forestry, Water, and Mines in Rwanda developed an implementation program for the land policy and law. The registrar of land titles maintained the registers and record. The district registrar convened community meetings and certified the legal documents to endorse the mapping in Mozambique [8]. They also formalized community groups. In Rwanda, the Commissions scrutinized disputes arising in the regularization process and ensured the participation of communities. The district institution in Rwanda maintained the land records and archives and in some cases was responsible for the authorization and approval of the plans submitted by communities in respect of their land governance and use [50]. The government of Uganda made it mandatory for women to be included in the customary land mapping decision-making processes [49]. The formal recognition of women's land claims and use of common lands in customary mapping exercises increased the potential for women to secure customary land tenure status by capturing and increasing the visibility of these claims. This made it easier for women to prove and defend their claims on customary lands in the various decision-making and registration forums. All the cited governments 
mobilized political will—an often overlooked but strategic precondition for realizing women's land tenure security. Civil society, women's groups, and community organizations provide expertise and local knowledge; support the change once the intervention has ended [46]. Local Civil Society Organizations (CSOs) often facilitate the mapping exercise and acted as mediating agents between the community and the mapping technicians, either from the private or public sectors. In Rwanda, the CSOs that have participated in the implementation of mapping initiatives have been responsible for enhancing the conflict resolution capacity of the traditional leaders and raising women's awareness about land rights. In Uganda, the Uganda Land Alliance, a civil society organization supported the organization and registration of local communities to enable them to have legal entities which they could use to register their land claims. The Uganda Land Alliance presided over election of the management committees and ensured that each management committee of nine had at least three women members [49]. Other civil society organizations supported raising communities' awareness of gender issues and providing training for the central and local government stakeholders. In Rwanda, the Rwanda Initiative for Sustainable Development (RISD), a local Civil society organization ensured that women's views were heard by soliciting the views of the grassroots women to be considered [50].

In Kiepersol, South Africa, researchers worked with communities to explore the dynamics in a land claim case where community members mapped their heritage claims. The communities led the research team to their former homelands and identified significant places like graveyards and places they played when they were younger [47]. Similarly, the village level committees in Tanzania have been responsible for managing land and establishing and administering local registers of communal land rights, issuing certificates of customary land rights, and managing the land. Communities may delineate land according to customary use including forests, habitats, and sites of cultural and historical importance. Communities also have a role in the validation of boundaries occupation and land use [8].

\subsection{Legal Status of the Mapping Outputs}

The legal status of the maps and outputs of the interventions is important as it informs the extent to which the outcomes of these innovative interventions can be used to secure women's land tenure in a customary land tenure area. In Rwanda, the information was entered into the Land Tenure Regularization Support System [33] and used for titling purposes. In Madagascar, the information generated was used to develop land occupation plans and grant certificates of occupation [33]. By contrast, despite the immense effort that was undertaken by IDLO, SDI, CTV, and LEMU in implementing the Community Lands Titling Initiative in Liberia, Mozambique, and Uganda, at the time of project report publication in 2012, none of the participating communities had managed to receive formal documentation in recognition of their communal territorial claims [35]. These ambiguous project outcomes notwithstanding, however, in Uganda financial institutions are required by law to accept the legitimacy of the Certificate of Communal Ownership (CCOs) created from community mapping exercises as valid titles and as such, those communities that had managed to complete and submit their applications for a CCO or for freehold titles stood a better chance of leveraging their ownership for land investment purposes or for the facilitation of sale. In order to increase the legitimacy of maps, the maps must be prepared to government standards and guidelines. At the time of the publication of the project in 2015, 52 communities whose lands and mapping were ready were still waiting for the registration certificate from the government of Uganda [41].

In Uganda, communal area land governance is fragmented among the various ministries and managed by various often overlapping land governance institutions. These include the district land boards, land tribunals, local land courts, and customary institutions [41,46]. The 1988 Land Act which conferred legal rights to customary tenure land rights and the 2013 Land policy that recognized customary land tenure as being at par with other land tenure systems in Uganda, increased the opportunity for communities and women within them to secure their customary land tenure rights. The consolidation of the customary and statutory land governance systems potentially removed 
loopholes between the two systems which are exploited by the powerful to undermine women's land tenure in customary land tenure areas.

In the reducing emissions from deforestation and forest degradation (REDD) initiative in the DRC, the maps were officially recognized by the relevant authorities. The WWF worked with community partners and administrative authorities to facilitate the process required to obtain official recognition of community maps. This process of recognition begins with the Local Territory Administration and continues through to the District Commissioner, Provincial Interior Ministry and, finally, the National Interior Ministry. The maps and numerical data gathered have been shared with institutions, including Institute Géographique du Congo and Institut National de la Statistique at the national and provincial levels. Printed maps are distributed to communities, customary authorities, including land chiefs, and the territory administrators [34]. Beyond the mapping exercise undertaken by IDLO and CTV in Mozambique, other donor-sponsored community land ownership regularization initiatives have, following the delineation, produced a map of the community DUAT with any other information, such as rights-of-way, which has then been registered in the Cadastral Atlas, culminating with the issuing of a Certificate of Delimitation in the name of the community [33]. In Rwanda, the maps generated were recognized at law as legal documents [10].

\subsection{Impact of Customary Land Mapping on Women's Customary Land Rights}

The mapping exercises increased communities' awareness of women's claims and rights to land and related resources. The mapping enables communities to identify and increase awareness of the way in which women exploit natural resources like rangelands, water, and forests. This, for example, included the mapping of water routes which are often overlooked when large scale land resources are alienated and highlights the extra burden that women had to walk longer distances to secure water for domestic use. The maps also capture the women's dependence and use of forest produce and resources in ways that male biased mapping would not. The integration of women and communities into land use planning [8] enabled women to participate and increased their visibility. The recording of women's land rights on the maps and claims and routes to access water and forest produce increased the visibility of women's claims on land. The increased visibility means that women's concerns become represented in various forums.

The use of resource mapping techniques and community validation enabled women to highlight the vulnerability of the resources they use in relation to competing interest (for example, large scale land investors, the government, and powerful individuals in the communities). The Rwanda initiative used maps to identify winners and losers in the implementation of irrigation projects and in the implementation of irrigation schemes. This development made it possible for the project process to identify women and other vulnerable groups who often lose out of the large land-based investments like irrigation schemes where men are often better placed to capture the benefits from employment and subcontracting arrangements [50]. This increased the chances of women's issues and claims being taken into consideration in the assessment and mitigation of impacts and changes in land tenure and use.

The inclusion of women in the mapping process by granting equal recognition to women as community members, as legitimate members of local land governance structures, and as resource users, entrenched their interests in relation to land, water, and other natural resources. The protocols for mapping land and resource rights provide opportunities for women to participate in decision-making. In Mozambique, the Lei de Terras (1997) law makes it mandatory to include women in every step of registering community land. The Lei de Terras explicitly grants women equal rights in community property and their participation in every component of community land-related governance [8,39]. In Uganda, the 1988 Land Act, which provides for the establishment of Communal Land Associations for the purposes of managing communal land resources, specifies that a third of the Communal Land Association (CLA) executive committee members must be women. This provision has paved the way for the participation of women in the management of communal lands. The CLA is the legal 
entity that can map and register land on behalf of the community and as such, by making women's proportional representation a requirement, the Land Act has gone a significant way towards ensuring women's tenure security [49]. In Rwanda, the data and information collected for maps and spatial is gender disaggregated [50] to facilitate monitoring. The recognition of women as rightful actors and participants in decision-making processes goes some way towards increasing their security as they are consulted in decisions to alienate land, plan land use, allocate land, and or negotiate and enter into commercial agreements with outsiders. This recognition potentially enables women to benefit equally in compensation that may be paid out for the alienation of land. The other ways in which women's inclusion in decision-making in land matters included discussions with elders, raising community awareness, and training women to participate in the decision-making fora and following up on them [10].

Mapping initiatives potentially strengthen women's land rights in a marital union; the strategic, but unfortunately, increasingly unstable institution through which women traditionally gain access to customary land. The Benin MCC report recommended that the customary obligation of husbands to provide land to wives be captured at an individual level and other secondary rights, like communal rights to harvest, be captured in rural landholding plans (Plan Foncier Rural (PFR)). The report also recommended that the law and regulations, at a minimum, presume co-ownership of land between spouses and that a communication, education, and training plan be adopted to raise community's awareness and appreciation of these recommended developments [46].

Mapping initiatives such as the community land delimitation in Mozambique and community land registration in Uganda enable women to make significant progress towards gaining statutory recognition of customary land rights. In Mozambique and Uganda where women's land rights in customary areas were weak, the successful implementation of the mapping initiatives provided women with a form of statutorily recognized land rights and records. Participatory land and resource mapping can strengthen women's land rights in customary tenure areas by facilitating the recording of secondary land rights, which would otherwise remain invisible and ignored during transactions with outsiders and powerful institutions with an interest in the appropriation or acquisition of communal land and attendant resources. Where these derived rights to land are not made visible nor recognized as legitimate claims, the result in many instances is that women lose out on compensation and beneficiation claims. While not the panacea for enhanced tenure security for women, the recording of women's secondary land rights is a fundamental first step towards bringing the customary land rights into the public domain where other institutions (such as advocacy groupings and even judicial courts) can participate in the mediation of these rights [46].

The improved land and resource governance that resulted from the transparent and democratic processes that land governance institutions were subjected to increased women's land tenure security in customary areas as they were less vulnerable to corruption and gender-based violence. Widows and single women benefited from the transparency as their land rights were recorded in a medium other than people's memories. This provided them with an alternative platform for securing and defending their land rights. In Benin, the mapping went further by drawing specific maps of secondary rights and vulnerable groups and making a plan to protect and enhance their access to land [46].

In Rwanda, gender considerations are taken into account at every step of the mapping and registration process. This means that men and women are included in awareness campaigns and specific aspects related to women's land rights are spelled out; the data are disaggregated by sex; both men and women are involved in the identification of parcels and boundaries; the delineation team includes both men and women and all the data related to all the components of the family are registered including wives and daughters [50]. In the context of a delimited community, civil law provides a useful legal safeguard tool in this regard, since the ownership of the use right is shared by every single member of the community, meaning that decisions must legally be taken by women as well as by men, and cannot be mediated through households, traditional authorities, or other 
'representative' bodies (unless specifically mandated to do so). In reality, of course, there are challenges in the application of this tool [7].

In Benin and Lesotho, mainstreaming gender and amending gender-blind legislation was a precondition for the Millennium Challenge Account signing a compact with the respective countries. This catalyzed women's land tenure security to the top of the agenda, and it formed an integral part of all the developments during the projects. In Benin, this included mapping initiatives. As a result, women were included in decision-making. Experts were hired with the specific role of safeguarding women's interests in the planning phase of mapping programmers, ensuring their participation in these initiatives, and overseeing the development and incorporation of gender-sensitive indicators as part of the matrices for monitoring and measuring the success of outcomes. As a result, the stakeholders have had to commit to closing the gender gap in land access [46].

The formalizing of women's rights as part of the delimitation of community rights generated opportunities for women to negotiate and shift attitudes and approaches without coming into direct conflict with the status quo. Subjecting the maps to community validation at various stages also ensured that women's concerns are highlighted, and their views inform the mapping conceptualization and development process.

The arrangements made to transfer technology and skills potentially transfer important skills and competencies linked to land-use management to local communities [7,8]. Women and or women only groups were targeted in these capacity building initiatives [7,44]. This includes training of cartographers. This makes it possible for local communities to gain intimate knowledge of the techniques, technologies, and processes necessary to promote and promote their tenure land tenure. The IDLO initiatives transferred skills to community-based para-legals, capacitating them with the knowledge of relevant legislative provisions for instituting participatory processes for formal recognition of communal land rights. The para-legal—and communities, more generally—also obtained conflict resolution skills, which were critical for managing intra- and inter-community disputes over land boundaries and resource use arrangements. Overall, there was increased capacity on the part of the communities to make decisions and participate in natural resource governance structures and negotiations. Through the Millennium Challenge Account-funded project in Benin, the number of para-legal professionals in the mayoral administrations in twenty communes was increased, significantly improving the local governments' capacity to assist citizens, including women's groups, to make effective use of the maps, to negotiate, and conclude agreements for use and occupancy of lands of new proprietors or of communal reserves [46].

\subsection{Limits of Mapping for Securing Women's Land Tenure in Customary Areas}

Analyses of these initiatives for the reform of customary land management demonstrated their scope and importance but also their limits. Mapping initiatives, while encouraging, must be subjected to empirical scrutiny to assess the extent to which they have actually translated into real security of tenure beyond the lifespan of outsider-driven or facilitated mapping initiatives. Mapping initiatives are not only difficult to launch but necessarily involve processes that can prove costly. The costs, which include equipment and software licensing, are beyond the reach of poor communities and women who have limited economic opportunities to earn money. This can be mitigated to an extent by open source technology, the involvement of funding partners, and documenting or registering the community land as a meta-unit [8]. Mapping initiatives can potentially create new and or unearth long standing boundary conflicts within the community or between a community and its neighbors, which can increase pressure on tenuous women's communal land tenure rights. Participatory appraisal and boundary mapping can mediate boundary conflicts. This includes the inclusion of local community information on history, culture, social organization, spatial occupation, land use, population dynamics, and possible conflicts and their resolution in the mapping [4]. Since mapping initiatives and the space they open up for women to secure land rights in customary land tenure areas threaten power interests, they may be subject to resistance by those who are threatened who include patriarchal gate keepers. 
This is mediated by expressing the importance of gender issues in the early stages of project design and developing a plan to communicate to difference target audiences $[4,46]$.

The supply driven nature of the initiatives undermine sustainability of the project in the long term beyond the project period. It is important to monitor the project using gender disaggregated data and adjust methods and targets if necessary $[46,50]$. There is no guarantee that the local land administration institutions (the municipalities and the provincial cadastral services) will have the skills, tools, and capacity to maintain the cadastral registers [10]. In that regard, it is important to build capacity of local level institutions. This is done though providing technical tools and training to the decentralized institutions. This can be complimented by increasing communities' capacities to use the mapping processes to maintain the cadastral registers. Women should be integrated into these initiatives $[4,7,10]$. The real changes associated with the paper-based and paper-generating initiatives will remain beyond the reach of many women unless they are supported by interventions to support the largely illiterate rural women to secure the necessary documentation. This is mediated by simplifying and streamlining land titling processes and including knowledgeable women in the project [46] as well as securing enforcement mechanisms. There is a risk that land institutions will not recognize the maps and or the rights and claims represented on them. The risk is higher if the maps are not presented in a format that is not consistent with existing land right recording systems. In order to mitigate this risk, mapping initiatives should study and take into account existing systems so that the new information is compatible with existing records. For example, in the DRC, the team worked to ensure that all information and data from the participatory mapping exercises was incorporated into national databases [7]. Since the mapping processes and attendant conversations involve choices and discussions, there is a risk that women and women's interests may be overlooked or set aside by those who have power over the mapping process [4]. The mandatory representation of women in decision-making fora and entities formed to facilitate the mapping, implementing a women's empowerment/participation strategy and working to ensure women's full involvement in all community land documentation activities are all strategies to address this challenge $[8,46,48]$.

In the communities represented, women form diverse age groups class and positions of power [27,51-53]. The differentiation of women and communities, if not taken into account during the mapping, can create challenges. For example, negotiating land rights under customary law can put certain community members at a significant disadvantage, particularly for certain categories of women such as widows and divorcees that lack the social power and support to successfully assert their interests. The process can also potentially perpetuate existing inequalities by favoring those with power $[10,52]$ Mapping initiatives should identify vulnerable groups and put in place mechanisms to protect them as well as the acknowledgement of rights holders secondary and derived rights to land [46]. The choice by the mapping authors can also undermine women's land claims. For example, state law bias in recording marriage can marginalize those whose marriages are not recorded in Statute. This marginalizes the majority of women who are married under customary law and other informal conjugal unions. In order to mitigate the risk of disenfranchisement of people who held derived land rights, implementers can develop contract forms and processes to document secondary rights. This includes amending gender-blind legislation and recording and registration of women's secondary rights to land, which include the right to use their husband's land and customary obligation of husbands to provide land to wives be captured as a real right to land [46]. Mapping of community resources may expose vulnerable resources and communities to exploitation. As a result, the communities and women within them will be vulnerable to displacement and loss of land to commercial interests. In order to protect women within communities from marginalization during registration, communities can register lands as a collective. The mapping would reference customary boundaries and empower communities to control and regulate intracommunity land holdings and use to protect the vulnerable women $[4,8]$. The risk of women losing communal resource rights in the registration of mapping outcomes can be addressed through registration of women's rights to harvest produce from communal resources [46]. 


\section{Recommendations for Improving on the Practice and Scaling-Up of Mapping Initiatives}

Although mapping initiatives potentially catalyze the transmission of women's land rights, there is need for a longitudinal study, and impact-monitoring impacts are hard to gauge over the duration of a short-term project. The extended multi-year monitoring would require a different project timeline and funding model. The development partners' pilot and project approaches make it difficult to consolidate and entrench processes and practices. For sustainability: internally-driven participatory governance ethos and practice, it is important to work both at the level of the community (raising awareness about legislative framework, supporting community discussion of and implementation of actual mapping processes in a gender sensitive way) as well as at the level of the government. The latter is necessary not only to ensure that the practices of government officials on land governance become more inclusive and gender sensitive, but also to support the state itself in the timeous and efficient discharge of its functions in respect of issuing the communal/household land titles or other formal recognition of tenure [50]. The involvement of women may have to be negotiated at length with gate keepers and community elders. This is important in communities where women are traditionally excluded from decision-making on land matters. It is also important to train and build capacity of women to ensure they play an active role in these community structures [49]. Land mapping procedures and outcomes should take note of, and where possible, preserve and build upon the aspects of untitled customary tenure that already favor women, given that they are already accepted as legitimate in communities. Land tenure mapping initiatives in customary areas can work better for women's land rights if they also include community-specific gender analysis and crafting strategies to address gender disparities into their programs.

\section{Conclusions}

The paper, which draws from case studies in selected countries in Sub- Saharan Africa, has shown that customary land mapping initiatives are an innovation that, given certain conditions and resources, can potentially catalyze the transmission of women's customary land tenure rights in ways that increase tenure security. This is through providing women access to decision-making forums and facilitating women's participation in land registration processes. The initiatives that recognize women's derived land rights precipitate change of the terms on which women negotiate access to resources in communal areas, providing alternative identity to marriage and kinship-based systems, open up novel spaces between custom and statute, which potentially enable women to negotiate for customary land, and increasing the visibility of women's land interests and narratives in customary land tenure areas. However, mapping, if not handled carefully, can potentially undermine women's fragile land rights in customary land tenure areas by entrenching existing power asymmetries, complicating existing land recording systems, increasing the cost of securing land by disbursing costly technology, unearthing long standing conflicts which can increase pressure on fragile land claims. There is a need for mapping initiatives to address issues of sustainability, localization and scaling, and affordability to ensure that the intervention brings about demonstrated changes to women's land tenure status in customary land tenure areas.

Author Contributions: Conceptualization G.P. and L.M. Methodology G.P. and W.M., formal analysis, G.P. writing L.M. and G.P., review and editing G.P. and W.M. All authors have read and agreed to the published version of the manuscript.

Funding: This research received no external funding.

Conflicts of Interest: The authors declare no conflict of interest.

\section{References}

1. Alden Wily, L. Collective Land Ownership in the 21st Century: Overview of Global Trends. Land 2018, 7, 68. [CrossRef] 
2. Cotulla, L.; Toulmin, C.; Quan, J. Better Land Access for the Rural Poor. Lessons from Experience and Challenges Ahead; IIED: Hertfordshire, UK, 2006.

3. Paradza, G.; Sulle, E. Agrarian Struggles in Mozambique: Insights from Sugar Plantations. In Africa's Land Rush Rural Livelihoods and Agrarian Change; Hall, R., Scoones, I., Tsikata, D., Eds.; James Currey: Suffolk, UK, 2015; pp. 150-162.

4. Knight, R. Best Practices in Community Titling. 2010. Available online: https://www.files.ethz.ch/isn/139540/ Land_InceptionPaper.pdf (accessed on 30 July 2020).

5. Makura-Paradza, G. Single Women, Land and Livelihood Vulnerability in a Communal Area in Zimbabwe; Wageningen Academic Publishers: Wageningen, The Netherlands, 2010.

6. Walker, C. Piety in the Sky? Gender Policy and Land Reform in South Africa. J. Agrar. Chang. 2003, 3, $113-148$. [CrossRef]

7. World Wildlife Foundation. Strengthening Land Tenure Through Participatory Land Use Mapping in the Democratic Republic of Congo; World Wildlife Foundation Fact Sheet; World Wildlife Foundation: Gland, Switzerland, 2013.

8. Knight, R.; Adoko, J.; Auma, T.; Kaba, A.; Salomao, A.; Siakor, S.; Tankar, I. Protecting Community Lands and Resources; International Development Law Organization (IDLO): Rome, Italy, 2012.

9. Weyer, D.; Bezerra, C.; Vos, A. Participatory Mapping in a Developing Country Context: Lessons from South Africa. Land 2019, 8, 134. [CrossRef]

10. Di Gessa, S. Participatory Mapping as a Tool for Empowerment. Experiences and Lessons Learned from the ILC Network; International Land Coalition: Rome, Italy, 2008; Available online: https:/www.participatorymethods.org/sites/ participatorymethods.org/files/particpatory\%20mapping\%20as\%20a\%20tool\%20for\%20empowerment.pdf (accessed on 15 June 2020).

11. Van Den Brink, R.J.E. Land Reform in Mozambique; Agric and Rural Development Notes; The World Bank: Washington, DC, USA, 2008; pp. 2-4.

12. Agarwal, B. Gender, resistance and land: Interlinked struggles over resources and meanings in South Asia. J. Peasant Stud. 1994, 22, 81-125. [CrossRef]

13. Whitehead, A.; Tsikata, D. Policy Discourses on Women's Land Rights in Sub-Saharan Africa: The Implications of the Re-turn to the Customary. J. Agrar. Chang. 2003, 3, 67-112. [CrossRef]

14. Kachingwe, N. From Under Their Feet: A Think Piece on the Gender Dimensions of Land Grab in Africa. 2012. Available online: https://landportal.org/resource/actionaid/under-their-feet (accessed on 30 July 2020).

15. Cooper, E. Women and Inheritance in 5 Sub-Saharan African Countries: Opportunities and Challenges for Policy and Practice Changes. Ph.D. Thesis, University of Oxford, Oxford, UK, 2010.

16. Veit, P. Focus on Land Brief: Custom, Law and Women's Land Rights in Zambian Land. 2012. Available online: http://www.focusonland.com/fola/en/countries/brief-custom-law-and-womens-land-rights-in-zambia/ (accessed on 30 July 2020).

17. Peters, P. “Our daughters inherit our land, but our sons use their wives' fields": Matrilineal-matrilocal land tenure and the New Land Policy in Malawi. J. East. Afr. Stud. 2010, 4, 179-199. [CrossRef]

18. Cousins, B. Potentials and Pitfalls of "communal" land tenure reform: Experience in Africa and implications for South Africa. In Proceedings of the World Bank Conference on Land Governance in Support of the MDGs, Washington, DC, USA, 9-10 March 2009.

19. Berry, S. Hegemony on a shoestring: Indirect rule and access to agricultural land. Africa 1992, 62, 327-355. [CrossRef]

20. Lavigne-Delville, P. Harmonising Formal Law and Customary Land Rights in French-Speaking West Africa, London; IIED Issue Paper 86; IIED: London, UK, 1999.

21. Cousins, B. Debating communal tenure in Zimbabwe. J. Contemp. Afr. Stud. 1993, 12, 29-39. [CrossRef]

22. Spichiger, R.; Kabal, E. Gender Equality and Land Administration: The Case of Zambia. Available online: https://www.diis.dk/files/media/publications/import/extra/wp2014_gender-land-zambia_rachelspichiger_edna-kabal_web.pdf (accessed on 31 July 2020).

23. Women for Women International. "Women Inherit Wrappers, Men Inherit Fields" The Problem of Women's Access to Land in South. Kivu, Democratic Republic of Congo; Women for Women International: Washington, DC, USA, 2014; Available online: https://www.landportal.org/fr/library/resources/mokoro7093/\%E2\%80\%98womeninherit-wrappers-men-inherit-fields\%E2\%80\%99-problem-women $\%$ E2\%80\%99s-access-land (accessed on 20 July 2020). 
24. Du Plessis, W. African Indigenous Land Rights in a Private Ownership Paradigm. Potchefstroom Electron. Law J. Potchefstroomse Elektron. Regsblad 2012, 14, 45-69. [CrossRef]

25. Van Asperen, P.; Mulolwa, A. Improvement of Customary Tenure Security as Pro-Poor-Tool for Land Development-A Zambian Case Study; International Federation of Surveyors (FIG): Copenhagen, Denmark, 2006.

26. Mvududu, S.; McFadden, P. Reconceptualizing the Family in a Changing Southern African Environment; Women and Law in Southern Africa Research Trust: Harare, Zimbabwe, 2001.

27. Kameri-Mbote, P. Gender Issues in Land Tenure under Customary Law. Available online: http://www.ielrc. org/content/w0509.pdf (accessed on 31 July 2020).

28. Haddad, L.; Gillespie, S. Effective food and nutrition policy responses to HIV/AIDS: What we know and what we need to know. J. Int. Dev. 2001, 13, 487-511. [CrossRef]

29. Whitehead, A. Women, Men and African Agriculture. IDS Bull. 2003.

30. Chinsinga, B.; Chasukwa, M. Trapped Between Farm Input Subsidy Programme and the Green Belt Initiative: Malawi's Contemporary Agrarian Political Economy. In Africa's Land Rush Rural Livelihoods and Agrarian Change; Hall, R., Scoones, I., Tsikata, D., Eds.; James Currey: Suffolk, UK, 2015; pp. 132-149.

31. Chimhowu, A.; Woodhouse, P. Customary vs Private Property Rights? Dynamics and Trajectories of Vernacular Land Markets in Sub-Saharan Africa. J. Agrar. Chang. 2006, 6, 346-371. [CrossRef]

32. Peters, P. Inequality and Social Conflict Over Land in Africa. J. Agrar. Chang. 2004, 4, 269-314. [CrossRef]

33. Bruce, J.; Migot-Adholla, S. Searching for Land Tenure Security in Africa; Kendall/Hunt: Dubuque, IA, USA, 1994.

34. Deininger, K.; Binswanger, H. The Evolution of the World Banks' Land Policy; World Bank: Washington, DC, USA, 1999.

35. Berry, S. No Condition is Permanent; University of Wisconsin Press: Madison, WI, USA, 1993.

36. Meinzen-Dick, R.; Mwangi, E. Cutting the web of interests: Pitfalls of formalizing property rights. Land Use Policy 2009, 26, 36-43. [CrossRef]

37. Daley, E.; Englert, B. Securing land rights for women. J. East. Afr. Stud. 2010, 4, 91-113. [CrossRef]

38. Garber, B. Women's land rights and tenure security in Uganda: Experiences from Mbale, Apac and Ntugamo. Sociol. J. Afr. Stud. 2013, 13, 1-32.

39. Norfolk, S.; Turner, C. Improving Tenure Security for the Rural Poor Mozambique Case Study. Available online: http://www.fao.org/3/a-k0786e.pdf (accessed on 31 July 2020).

40. Yngstrom, I. Women, Wives and Land Rights in Africa: Situating Gender Beyond the Household in the Debate Over Land Policy and Changing Tenure Systems. Oxf. Dev. Stud. 2002, 30, 21-40. [CrossRef]

41. International Land Coalition. Gendered Impacts of Commercial Pressures on Land; International Land Coalition: Rome, Italy, 2011.

42. Hall, R.; Paradza, G. Pressures on Land in Sub-Saharan Africa: Social Differentiation and Societal Responses. Available online: https://www.academia.edu/2128927/ (accessed on 30 July 2020).

43. Joireman, S. The Mystery of Capital Formation in Sub-Saharan Africa: Women, Property Rights and Customary Law. World Dev. 2008, 36, 1233-1246. [CrossRef]

44. UN-Habitat/IFAD/GLTN. Using Approaches and Technologies for Mapping Land and Natural Resource Use and Rights; Tenure Security Learning Initiative for East and Southern Africa; IFAD: Rome, Italy, 2012; Available online: https://issuu.com/landgltn/docs/land_and_natural_resources_tenure_s/20 (accessed on 7 March 2020).

45. Tripathi, N.; Bhattarya, S. Integrating Indigenous Knowledge and GIS for Participatory Natural Resource Management:State-of-the-Practice. Electron. J. Inf. Syst. Dev. Ctries. 2004, 17, 1-13. [CrossRef]

46. Scalise, E.; Giovarelli, R.; Hannay, L.; Richardson, A. Gender and Land: Good Practices and Lessons from Four Millennium Challenge Compact Funded Projects. 2014. Available online: http://www.wocan.org/ resources/gender-and-land-good-practices-and-lessons-learned-four-millennium-challenge (accessed on 10 June 2015).

47. Rugadya, M.; Kamusiime, H. Tenure in Mystery: The Status of Land Under Wildlife, Forestry and Mining Concessions in Karamoja Region, Uganda. Nomadic Peoples 2013, 17, 33-65. [CrossRef]

48. Namulondo, P.; Paradza, G.; Cherlet, J. Communal Land Associations Claim Compensation for Investments in Their Territories, Karamoja, Uganda. Case Study; International Land Coalition Database of Good Practices: Rome, Italy, 2015.

49. Weiner, D.T.A.; Harris, T.M.; Levin, R.M. Apartheid Representations in a Digital Land Scape: GIs, Remote Sensing and Local Knowledge in Kiepersol, South Africa. Cartog. Geogr. Inf. Systt. 1995, 22, 30-44. 
50. Carpano, F. Strengthening Women's Access to Land into IFAD Projects: The Rwanda Experience. 2011. Available online: https://www.issuelab.org/resources/21153/21153.pdf (accessed on 2 February 2015).

51. Rugadya, M. Titling of Customary Tenure is Not a Fix for Women's Land Right: A Review of Evidence and Practice; Washington DC, USA. Available online: https://www.academia.edu/43491123/Titling_of_Customary_ Tenure_is_not_a_fix_for_Womens_Land_Right_a_review_of_Evidence_and_Practice (accessed on 13 July 2020).

52. Chigbu, U.; Paradza, G.; Dachaga, W. Differentiations in Women's Land Tenure Experiences: Implications for Women's Land Access and Tenure Security in Sub-Saharan Africa. Land 2019, 8, 22. [CrossRef]

53. Cousins, B.; Winer, D.; Amin, N. Social Differentiation in the Communal Lands of Zimbabwe. Rev. Afr. Political Econ. 1992, 19, 5-24. [CrossRef]

(C) 2020 by the authors. Licensee MDPI, Basel, Switzerland. This article is an open access article distributed under the terms and conditions of the Creative Commons Attribution (CC BY) license (http://creativecommons.org/licenses/by/4.0/). 